\title{
THE COMPETENCY GAP OF HOTEL MANAGEMENT GRADUATES FROM HOTEL SUPERVISOR'S PERSPECTIVE
}

\author{
ANDI TAMSANG ANDI KELE \\ SYED AZIZI WAFA SYED KHALID WAFA \\ School of Business \& Economics \\ Universiti Malaysia Sabah
}

\begin{abstract}
The hotel industry has gained prominence in Malaysia and with the global nature of the industry, human resource issues need to be addressed to ensure that the industry remains competitive. This quantitative research provides a comprehensive study on the competency gap of hotel management graduates from the employers' perspectives. This study looks at the expectation and observation of hotel supervisors towards hotel management graduates in Kota Kinabalu, Sabah. A total of 200 questionnaires were sent out to all the star-rated hotels in Kota Kinabalu, Sabah, and 100 usable responses were received and analysed. It was found out that there is a gap in terms of work-related competencies of the Hotel Management (HM) graduates from the hotel supervisor's perspective. It is suggested that the educational institutions and other training organizations pay attention to the results of this study since it was found that the hotel supervisors felt the work-related competency provided by the institutions where the HM graduates are trained is below their expectation and as such, it needs to be improved.
\end{abstract}

Keywords: Hotel Management Graduates, Competency, Gap, Hotel Management Programme, Sabah.

\section{Introduction}

The Malaysian hospitality industry relies heavily on the tourism sector for its survival. The state of Sabah saw an increase in tourist arrivals of almost 108 per cent from $1,251,454$ to $2,844,597$ tourists between the years of 2003 to 2011 (Table 1). The increasing trend in terms of tourist arrivals in Sabah also had contributed to the rapid demand for hotel accommodation and its supporting activities. According to the Malaysian Association of Hotels (2012), Sabah had a total of 135 star-rated hotels in 2011 as compared to 52 in 2006 . To meet the demands of this rapidly expanding hospitality industry, urgent measures are needed to increase the supply of skilled personnel (Goldsmith \& Salehuddin, 1994). This has led to the continuous growth of public and private institutions in Sabah which offer hotel management courses to fill the workforce needs of these hotels. Despite the increasing number of hotel graduates, hotels are still facing worker shortages (Malaysian Association of Hotels, 2011).

The prime minister of Malaysia, Dato' Sri Mohd Najib b. Tun Abdul Razak urges 
universities to work closely with the industrial sector in co-curriculum development, to ensure they produce graduates that are relevant to the industry. The cooperation is crucial in avoiding serious gaps in graduate competency produced by local universities and those needed by the industry. University cocurriculum must be compatible and relevant to the industrial sector's requirements (Ram, 2006).

Table 1

Tourist Arrivals in Sabah from Year 2003-2011

\begin{tabular}{lc}
\hline Year & Number of Tourist Arrivals \\
\hline 2003 & $1,251,454$ \\
2004 & $1,773,271$ \\
2006 & $2,091,658$ \\
2007 & $2,478,443$ \\
2008 & $2,300,428$ \\
2009 & $2,246,068$ \\
2010 & $2,504,669$ \\
2011 & $2,844,597$ \\
\hline
\end{tabular}

Source. Sabah Tourism Board (2012).

With the effort of the Higher Education Institutions (HEI) in Malaysia, large numbers of graduates were produced each year. Nonetheless, the percentages of the graduates who got a jobs at the end of the day was surprisingly low (Goldsmith \& Salehuddin, 1994). According to the statistics released by the Ministry of Higher Education of Malaysia on the graduates tracer study in 2011, out of 184,381 graduates, 24 per cent were unemployed. The number of unemployed graduates was 44,391 as shown in Table 2.

In addition, Universiti Malaysia Sabah's tracer study on the Hotel Management (HM) graduates employment status in Table 3 also shows that the unemployment rate in 2011 was 15 per cent compared to 26 per cent in 2010. Even though the number is decreasing, it is still significantly high. So, the statistical data shows that the graduates that have been produced by the HEI may not meet the employers' needs.

With the increasing number of $\mathrm{HM}$ graduates in Sabah, questions regarding the competency of HM graduates and their value to the employer has emerged. This was supported by Lennon (1989), who stated that considerable difficulties are encountered in attempting to ascertain industry needs in an educational context. Apart from that, Ricci (2005) also stated that many educators do not understand what the employer seeks from graduates of HM studies, and the employer does not know what a HM degree consists of. Therefore, there is a need to identify the competency gap of HM graduates from the employers' perspective. 
Table 2

Graduates Tracer Study 2011

\begin{tabular}{ccc}
\hline Employment status & Total Number & Percentage (\%) \\
\hline Employed & 96,973 & 52.5 \\
Further studies & 31,645 & 17.1 \\
Improving skills & 2,552 & 1.4 \\
Waiting for job placement & 9,020 & 4.9 \\
Unemployed & 44,391 & 24 \\
\hline Total & 184,381 & 100 \\
\hline
\end{tabular}

Source. Statistics of Higher Education of Malaysia 2011.

Table 3

HM Graduate Employment Rate in UMS from 2010-2011

\begin{tabular}{ccccc}
\hline Employment status & Total Number & Percentage (\%) & Total Number & Percentage (\%) \\
\hline Employed & 17 & 35.5 & 32 & 63 \\
Further studies & 5 & 10.5 & 4 & 8 \\
Unemployed & 26 & 54 & 15 & 29 \\
\hline Total & 48 & 100 & 51 & 100 \\
\hline
\end{tabular}

Source. Malaysian Ministry of Higher Education, 2011.

\section{Review of the Literature}

In order to conceptualize the competency gap from the employers' perspectives, the discrepancy theory was used to explain the difference between the expected and the observed competency of HM graduates. Based on the discrepancy theory, satisfaction was impacted by the discrepancy between the competency that employers expected and the observed competency level of new hires. The discrepancy theory asserts than an individual's satisfaction was related to the extent to which outcomes match those desires (Locke, 1976). This psychological comparison produces both positive and negative discrepancies. Positive discrepancies are experienced when the perceived competency is greater than the standard of comparison, which is the expected competency. Negative discrepancies are indicated when HM graduates are observed based on performance at a lower expectation level. 
David McClelland, a former Harvard psychologist, first tested competence in the early 1970s (Mirablle, 1997). McClelland was asked by the United States Foreign Service to find new research methods that can predict human performance and reduce the dependence on traditional intelligence and aptitude testing. This task resulted in the establishment of competency as an educational tool. Since then, competency has became a significant field of study that has been revised by other scholars. Nath \& Raheja (2001) posted this widely accepted definition, "Competency is a combination of observable and applied knowledge, skills and behaviours that create competitive value and what is actually accomplished". Competencies can be accumulated within an individual and represent a capacity to perform at some future point (Nath \& Reheja, 2001). Essentially, these definitions relate to enduring characteristics possessed by individuals that, under normal circumstances, result in an acceptable or superior job performance. This notion is based on the premise that competencies are causally linked to individual performance outcomes (Spencer \& Spencer, 1993).

In order to get a clearer picture of what competency is, frameworks have been developed. Brophy and Kiely (2002) declared that competency frameworks can be applied in many ways and offer an integrated approach to human resource management that included 360-degree feedback, succession planning, training and development, recruitment and selection, and performance appraisals. Nath and Raheja (2001) declared that possession of the competencies enables an individual to perform the required function much better than others who do not possess the relevant competencies. Conceptual, leadership, administrative, interpersonal and technical skills were recognized as important competencies for a management position in the hospitality industry (Sandwith, 1993; Dunne, Benneth, \& Carre, 1999; Curtis \& McKenzie, 2001).

For this study, competency gap refers to the hotel supervisors' perception, their expectation and observed competency of the HM graduates. According to Tsai, Goh and Huffmann (2006), perception is a process by which individuals organize and interpret their sensory perceptions in order to give meaning to their environment. However, what one perceives can be substantially different from reality (Tsai et al., 2006). Perception depends not only on the physical stimuli, but also on the stimuli's relation to the surrounding field and on conditions within the individual. When an individual looks at a target and attempts to interpret what he or she sees, that interpretation is heavily influenced by the personal characteristics of the individual perceiver. Personal characteristics that affect perception include a person's attitude, interest, past experiences, and expectations. So, in order to measure the hotel management graduates' competency, this study adopted Sandwith's (1993) managerial competencydomain model, which included conceptual, leadership, administrative, interpersonal, and technical skills.

The Sandwith's competency-domain model framework was widely used by scholars in assessing graduates' competency. The domain model consists of: the conceptual approach focusing on the cognitive skills needed for the job; leadership referring to the ability to translate ideas into productive actions; interpersonal skills for effective interaction; administrative to the personal and financial management of the business, and technical which is the knowledge and skills essential to producing the product or services. 


\section{Research Methodology}

The discrepancy theory was used to explain the difference between the expected and the observed competency of HM graduates from the hotel supervisor's perspective. The discrepancy theory asserts than an individual's satisfaction is related to the extent to which outcomes match desires (Locke, 1976). Therefore, the hypothesis for this study is to find out whether there is a significant difference between the hotel supervisor's expected and observed competency of the HM graduates.

Measuring Instrument. Data was collected by means of a questionnaire, developed according to the five dimensions: leadership, interpersonal, technical, conceptual, and administrative competencies. Questions were adopted from the study conducted by Tsai, Goh, and Huffman (2006). The questionnaire setups for this study were structure questions that consisted of 32 closed-ended questions that required the respondent to choose from a predetermined set of responses or scale points. The type of scale utilized in this study was the Likert Summated Rating Scale with a scale of one to five. It provided a method for the respondent to express the intensity of feeling about their expected and observed competency of HM graduates. According to Tsai (2006), one to five on the Likert scale was the best measurement to study the competency gap. Each respondent would be asked to indicate the extent of his or her agreement with the statement. The extent of disagreement or agreement becomes a point along a predefined scale measuring responses. The basis of evaluating the criteria is a five-point Likert scale ranging from "very low" to "very high". In the questionnaire, there were two columns of measurement to measure the expected competency and perceived competency observed which also consistently used the five-point Likert scale. The Cronbach Alpha for the variable obtained was 0.956 .

Sampling. A total of 100 hotel supervisors were selected. The selected hotel supervisors were drawn from one-to five-star hotels which were located in Kota Kinabalu, Sabah. The main characteristic of the population sample was that all the respondents were at supervisory level or above. The underlying assumption on the population sample was that the respondents had supervised and evaluated their subordinates that have graduated from Malaysian colleges and universities.

\section{Results of the Study}

A total of 200 questionnaires were distributed among the hotel supervisors of the star-rated hotels in Kota Kinabalu, which included Deleeton Hotel (one star), Kinabalu Daya Hotel and Tang Dynasty Bay (two star), Jesselton Hotel and Shangri-La Hotel (three star), Beverly Hotel (four-star hotel), and Shangri-La Tanjung Aru Resort and SPA (five star). The respondents were given three weeks to respond. However, only 108 questionnaires were returned. Out of the 108 questionnaires, 8 were rejected after the screening process. A total of 92 questionnaires were not returned by the respondents, making it a 55 per cent response rate.

Regarding the respondent's education, about 21 per cent indicated that they had obtained secondary level education, 30 per cent were certificate holders, 22 per cent were diploma holders, 19 per cent were degree holders, 6 per cent were masters holders and 2 per cent were PhD holders. 
Table 4

Profile of Respondents

\begin{tabular}{|c|c|c|c|}
\hline Profile & Description & Frequency & Percentage $(\%)$ \\
\hline Highest Education & Secondary School & 21 & 21 \\
\hline \multirow[t]{5}{*}{ Level } & Certificate & 30 & 30 \\
\hline & Diploma & 22 & 22 \\
\hline & Bachelor Degree & 19 & 19 \\
\hline & Masters & 6 & 6 \\
\hline & $\mathrm{PhD}$ & 2 & 2 \\
\hline \multirow[t]{5}{*}{ Organization } & 1 - Star Hotel & 24 & 24 \\
\hline & 2 - Star Hotel & 9 & 9 \\
\hline & 3 - Star Hotel & 39 & 39 \\
\hline & 4 - Star Hotel & 15 & 15 \\
\hline & 5 - Star Hotel & 13 & 13 \\
\hline \multirow[t]{4}{*}{ Functional Area } & Front Office & 42 & 42 \\
\hline & Housekeeping & 19 & 19 \\
\hline & Kitchen & 15 & 15 \\
\hline & Human Resource & 24 & 24 \\
\hline Length of & $6-10$ & 55 & 55 \\
\hline experience in the & $11-15$ & 27 & 27 \\
\hline \multirow[t]{2}{*}{ hotel Industry } & $16-20$ & 11 & 11 \\
\hline & $21-25$ & 7 & 7 \\
\hline
\end{tabular}

For the 'organization' category, it was an open question and later divided into five groups of star rated hotels. 24 per cent of the respondents were from one-star hotel, 9 per cent were from two-star hotels, 39 per cent were from three-star hotels, 15 per cent were from four-star hotels and the remaining 13 per cent were from five-star hotels. The 'functional area' category was also an open question that was divided into 4 groups; 42 per cent of the respondent were from the office department, 19 per cent were from the housekeeping department, 15 per cent were from the food and beverage department, and 24 per cent were from the human resource department. For the 'experience' category, the respondents were asked to fill their exact length of experience, which was later divided into four groups as shown in Table 4 which summarizes the profile of the respondents. 
The smallest percentage of 7 per cent was respondents who had between 21 to 25 years of experience while the largest percentage of 55 per cent was the respondents who had 6 to 10 years of experience. The respondents who were in the experience range of 11 to 15 years and 16 to 20 years made up the remaining 27 per cent and 11 per cent respectively.

Factor analysis was conducted to reduce a large number of related variables to a more manageable number, prior to using them in other analyses. For this study, the competency statement for gap analysis consisted of five dimensions - conceptual, interpersonal, leadership, technical and administrative. Initially there were 32 items in the dependent variables, nevertheless, after the factor analysis, 14 items were deleted and the remaining 18 items were grouped into two new categories. The categories were identified as people-related dimension (interpersonal and leadership) and taskrelated dimension (conceptual, technical and administrative). For this study, the Cronbach's Alpha of the dependant variable (competency gap) was 0.956 with 18 items. The descriptive statistics in Table 5 presents the mean, standard deviation, minimum value and maximum value of the variables.

Table 5

Descriptives for variables

\begin{tabular}{ccccc}
\hline \multicolumn{1}{c}{ Variables } & Means & Standard Deviation & Min. & Max. \\
\hline Expected Competency & 3.4756 & 0.53423 & 2.11 & 4.44 \\
Observed Competency & 3.3172 & 0.66194 & 1.94 & 4.39 \\
Competency Gap & -0.1583 & 0.86652 & -1.89 & 2.28 \\
\hline
\end{tabular}

Table 6

Paired T-Test

\begin{tabular}{ccccc}
\hline & & $\mathrm{t}$ & $\mathrm{df}$ & Sig. (2-tailed) \\
\hline & Expectation - Observation & 1.827 & 99 & .071 \\
Expectation - Observation & -1.677 & 99 & .097 \\
& $\begin{array}{c}\text { (Human Related Competencies) } \\
\text { Expectation - Observation }\end{array}$ & 4.057 & 99 & .000 \\
& (Task Related Competencies) & & & \\
1-Star Hotel & Human-related Competencies & -8.898 & 23 & .000 \\
& Task-related Competencies & -2.563 & 23 & .017 \\
\hline
\end{tabular}




\begin{tabular}{lcccc}
\hline & & $\mathrm{t}$ & $\mathrm{df}$ & Sig. (2-tailed) \\
\hline \multirow{2}{*}{ 2-Star Hotel } & Human-related Competencies & -4.482 & 8 & .002 \\
& Task-related Competencies & -2.525 & 8 & .036 \\
3-Star Hotel & Human-related Competencies & .088 & 38 & .930 \\
& Task-related Competencies & 3.225 & 38 & .003 \\
\multirow{2}{*}{ 4-Star Hotel } & Human-related Competencies & 3.927 & 14 & .002 \\
& Task-related Competencies & 5.356 & 14 & .000 \\
5-Star Hotel & Human-related Competencies & 4.739 & 12 & .000 \\
& Task-related Competencies & 9.343 & 12 & .000 \\
\hline
\end{tabular}

Hypothesis: There is a significant difference between the hotel supervisor's expected and observed competency of the HM graduates.

The results obtained from the paired T-test are shown in Table 6. It shows that the overall significance result value $(\mathrm{p}>0.05) \mathrm{p}=0.071$. Therefore, there is no significant difference - between the hotel supervisors' expected and observed competency of HM graduate. Even though there is no overall significant difference between the hotel supervisor's expected and observed competency the paired T-test for task-related competencies shows a significant difference as the $\mathrm{p}$-value is 0.000 . Based on star-rated respondents, supervisors of four-and five-star hotels are significant both in terms of human-related and task-related competencies.

\section{Discussion and Conclusion}

The findings in this study indicated that there is no significant difference between the hotel supervisors' expected and observed competency of hotel management graduates in Kota Kinabalu, Sabah. The result also shows that there is no significant difference between expected and observed competency regarding people-related competencies. However, the result indicates that there is a significant difference between the expected and observed competency of HM graduates in terms of task-related competencies. This result supports the findings of Cappel (2001) and Hills, Robertson, Walker, Adey and Nixon (2003) who found that the gaps between expected and actual performance tended to be greater for technical skills. In other words, hotel supervisors expected higher task-related competencies technically, administratively and conceptually.

Based on star-rated respondents, supervisors of four-and five-star hotels show significant difference for both humanrelated and task-related competencies. Fourand five-star hotels have to face severe challenge compared to other star hotels due to the scope of management and the expectation to reach the quality expected. So their expectations for the HM graduates are greater for both human-related and taskrelated competencies for them to fulfill the task given. It appears that both human-related and task-related competencies are necessary 
to operate effectively in the hospitality industry (Kim, 2008).

This finding suggests that the higher educational institutions may have to revise or strengthen their current syllabus especially on the conceptual, technical and administrative aspects of their curriculum apart from leadership and interpersonal competencies. With the increasing number of HM graduates from colleges and universities in Sabah, it is imperative that these educational institutions collaborate closely with the industry to ensure that HM graduates will be relevant for the industry and can be quickly and effectively absorbed by the hotels.

There are some limitations for this study. The scope of this study is limited to starrated hotel supervisors in Kota Kinabalu. As such, it does not represent the competency gap of HM graduates throughout Sabah or Malaysia. Therefore, the result obtained cannot be generalized. Apart from that, the questionnaire used for this study was adopted and modified from previous scholars. However, it was considered long and complex with a total of 32 questions. The competency questions were divided into two, namely expectation and observed. This adds to the complexity of the questionnaire. As responding is a voluntary process, the risk of boredom and exhaustion may lead to half-done questionnaires. Moreover, the comprehension level of the respondents to the questions and the accuracy of their answers cannot be determined.

Finally, it is hoped that this study has played its part in contributing to domestic and global research on hotel management education. Further studies should lead to a more sustainable and replicable model that is able to guide both the hotel and the education industries in understanding the competency gap of the HM graduates.

\section{References}

Brophy, M., \& Kiely, T. (2002). Competencies: A new sector. Journal of European Industrial Training, 26(2), 165-177.

Cappel, J. J. (2001). Entry-level IS job skills: A survey of employers. Journal of Computer Information Systems, 42(2), 76-82.

Curtis, D., \& McKenzie, P. (2001). Employability skills for Australian industry: Literature review and framework development. Australian Council for Education Research, Melbourne.

Dunne, E., Bennett, N., \& Carre, C. (Eds.). (1999). Core skills: Interpretations in higher education, in Dunne. The Learning Society: International Perspectives on Core Skills in Higher Education, Kogan Page, London.

Goldsmith, A., \& Mohd Salehuddin Mohd Zahari. (1994). Hospitality education in Malaysia: Filling the skill gap. InternationalJournalofContemporary Hospitality Management, 6(6), 27 31.

Hills, J. M., Robertson, G., Walker, R., Adey, M.A., \& Nixon, I. (2003). Bridging the gap between degree programme curricula and employability through implementation of work-related learning. Teaching in Higher Education, 8(2), 211-231.

Kim, J. H. (2008). Career expectations and requirements of undergraduate hospitality students and the hospitality industry: An analysis of differences (Unpublished Masters Degree). AUT University, Auckland, New Zealand. 
Lennon, J. J. (1989). Industrial "needs" and education provision: The case of hotel and catering management. InternationalJournalofContemporary Hospitality Management, 8(2), 111120.

Locke, E. A. (Ed.). (1976). The nature and causes of job satisfaction. Handbook of Industrial and Organizational Psychology, Rand McNally, Chicago, IL.

Malaysian Association of Hotels. (2012). Hotel rating. Retrieved from http:// www.hotels.org.my/images/pdf/ hotel_statistic/Hotels_Rating_ Dec_2011.pdf

Malaysian Association of Hotels. (2011). Surveys. Retrieved from http://www.hotels.org.my/home. asp?hdnMRef=58

Malaysian Ministry of Higher Education. (2011). Graduates tracer study. Putrajaya: Ministry of Higher Education.

Graduate Tracer Study (2011). Statistics of higher education of Malaysia 2011. Putrajaya: Ministry of Higher Education.

Mirabile, J. R. (1997). Everything you wanted to know about competency modeling. Training \& Development, August, 73-77.
Nath R., \& Raheja, R. (2001). Competencies in hospitality industry. Journal of Service Research, 7(1), 25-33.

Ram, S. (2006). 70\% of grads from public institutions jobless. Retrieved from http://sun2surf.com/article. $\mathrm{cfm}$ ? id $=14660$

Ricci, P. (2005). A comparative analysis of job competency expectation for new hires: The relative value of a hospitality management degree. (Doctoral dissertation), University of Central Florida Orland, Florida.

Tsai, F. C., Goh, B. K., \& Huffman, L. (2006). Bridging hospitality education and the industry: A delphi study of competency assessment for lodging entry-level. Management Trainees in Taiwan Chinese Economy Issue, 39(6), 49-69.

Sabah Tourism Board. (2012). Tourists arrival in Sabah. Retrieved from http:// www.sabahtourism.com/corporate/ visitor-arrival-statistics

Sandwith, P. (1993). A hierarchy of management training requirements: The competency domain model. Public Personnel Management, 22(1), 43-62.

Spencer, L. M. Jr., \& Spencer, S. (1993). Competence at work: Models for superior performance. New York: John Wiley and Sons. 